\title{
PERBANDINGAN KADAR EUGENOL MINYAK ATSIRI BUNGA CENGKEH (Syzygium aromaticum (L.) Meer. \& Perry) DARI MALUKU, SUMATERA, SULAWESI, DAN JAWA DENGAN METODE GC-MS
}

\section{DETERMINATION OF EUGENOL CONTENT IN CLOVE BUD ESSENTIAL OILS (Syzygium aromaticum (L.) Meer. \& Perry) FROM MALUKU, SUMATERA, SULAWESI, AND JAVA BY GC-MS METHOD}

\author{
Elsari Dwi Harnani, Muhammad Da’i, Rima Munawaroh` \\ Fakultas Farmasi, Universitas Muhammadiyah Surakarta \\ safirasyifa@yahoo.com
}

\begin{abstract}
ABSTRAK
Senyawa eugenol merupakan komponen mayor minyak atsiri bunga cengkeh yang mempunyai aktivitas antioksidan, antifungi, analgesik, dan antiseptik. Tujuan penelitian ini adalah menetapkan kadar eugenol minyak atsiri bunga cengkeh dari beberapa daerah sentra penghasil (Maluku, Sumatera, Sulawesi, dan Jawa).. Sampel minyak atsiri bunga cengkeh (Syzygium aromaticum L.) diperoleh melalui metode destilasi uap dan air. Kandungan eugenol dalam minyak atsiri bunga cengkeh dianalisis secara kualitatif dan kuantitatif dengan menggunakan GC-MS. Analisis menggunakan kolom kapiler Rxi ${ }^{T M}-1 \mathrm{~ms}$, kecepatan alir fase gerak helium 0,1 $\mathrm{mL} / \mathrm{menit}$, energi ionisasi $70 \mathrm{eV}$ dan temperature programming $50-100^{\circ} \mathrm{C}$ (kenaikan $10^{\circ} \mathrm{C} /$ menit dan ditahan 1 menit), $100-140^{\circ} \mathrm{C}$ (kenaikan $5^{\circ} \mathrm{C} /$ menit), $140-160^{\circ} \mathrm{C}$ (kenaikan $2^{\circ} \mathrm{C} /$ menit), dan $160-245^{\circ} \mathrm{C}$ (kenaikan $5^{\circ} \mathrm{C} /$ menit). Hasil penelitian menunjukkan kadar eugenol dalam minyak atsiri bunga cengkeh dari Maluku, Sumatera, Sulawesi, dan Jawa berturut-turut $93,17 \pm 1,72 \% \mathrm{~b} / \mathrm{b}$, $60,29 \pm 0,67 \% \mathrm{~b} / \mathrm{b}, 65,66 \pm 0,80 \% \mathrm{~b} / \mathrm{b}$, dan 55,88 $\pm 0,98 \% \mathrm{~b} / \mathrm{b}$. Minyak atsiri bunga cengkeh dari Maluku memiliki kualitas yang paling baik terkait kadar eugenol yang terkandung.
\end{abstract}

Kata kunci: Minyak atsiri, bunga cengkeh, Syzygium aromaticum, eugenol, GC-MS

\section{ABSTRACT}

Eugenol is major component of clove bud essential oils and it has activities as antioxidant, antifungi, analgesic, and antiseptic. The aim of this work was to determine eugenol composition of clove bud essential oils in several producer central regions (Maluku, Sumatera, Sulawesi and Java). Sample of clove bud essential oils (Syzygium aromaticum L.) were obtained by water and steam distillation method. Eugenol in clove bud essential oils was qualitatively and quantitatively analyzed by GC-MS. Analysis used Rxi ${ }^{T M}-1 \mathrm{~ms}$ capillary column, helium as mobile phase with flow $0.1 \mathrm{~mL} / \mathrm{min}$, ionization energy $70 \mathrm{eV}$, and temperature programming $50-100^{\circ} \mathrm{C}$ (increase at $10^{\circ} \mathrm{C} /$ minute and with hold time for 1 minute), $100-140^{\circ} \mathrm{C}$ (increase at $5^{\circ} \mathrm{C} /$ minute), $140-160^{\circ} \mathrm{C}$ (increase at $2^{\circ} \mathrm{C}$ /minute), dan $160-245^{\circ} \mathrm{C}$ (increase at $5^{\circ} \mathrm{C} /$ minute). The result showed that eugenol compounds in clove bud essential oils of Maluku, Sumatera, Sulawesi and Java were successively $93.17 \pm 1.72 \% \mathrm{~b} / \mathrm{b}, 60.29 \pm 0.67 \% \mathrm{~b} / \mathrm{b}, 65.66 \pm 0.80 \% \mathrm{~b} / \mathrm{b}$, and $55.88 \pm 0.98 \% \mathrm{~b} / \mathrm{b}$. Maluku's clove bud essential oils had the best quality based on its eugenol content.

Keywords: Essential oils, clove bud, Syzygium aromaticum, eugenol, GC-MS

\section{PENDAHULUAN}

Tanaman cengkeh (Syzygium aromaticum L.) merupakan jenis tanaman penghasil minyak atsiri yang tumbuh subur di Indonesia. Hal ini menunjang potensi Indonesia sebagai penghasil minyak cengkeh dalam jumlah besar (Busroni, 2000) bahkan produk minyak atsiri cengkeh Indonesia cukup dominan menguasai pasar dunia yaitu sekitar 2500 ton per tahun (Gunawan, 2009). Indonesia adalah negara penghasil minyak cengkeh terbesar sehingga pemanfaatan minyak cengkeh dapat dilakukan secara optimal dari segi agrobisnis dan untuk dunia pendidikan (Busroni, 2000).

Komoditi minyak cengkeh Indonesia secara garis besar masih diekspor keluar negeri dalam bentuk bahan mentah dan hanya sebagian kecil yang diekspor dalam bentuk senyawa eugenol (Busroni, 2000). Kebutuhan eugenol sebagian besar masih diimpor untuk memenuhi kebutuhan industri makanan, minuman, dan farmasi. Volume impor berkisar antara 138,8-174,2 ton/tahun dengan nilai USD 1,191-1,3 juta (Anonim, 2008). Senyawa eugenol diproses lebih lanjut menjadi berbagai 
produk dengan kegunaan lebih untuk dijual kembali dengan harga yang lebih tinggi, sehingga diperoleh nilai tambah serta keuntungan yang tidak sedikit bagi negara importir (Busroni, 2000). Meskipun beberapa perusahaan di dalam negeri mulai memproduksi eugenol murni dan isoeugenol, jumlahnya belum mampu memenuhi kebutuhan (Anonim, 2008).

Eugenol memegang peranan penting sebagai bahan dasar pembuatan produk dalam industri farmasi. Proses lebih lanjut dari eugenol dapat menghasilkan isoeugenol, eugenol asetat, dan vanilin yang merupakan bahan baku industri parfum, dan makanan. Industri kesehatan gigi (obat kumur, pasta dan formulasi bahan penambal gigi) menggunakan bahan baku eugenol dalam minyak cengkeh karena mempunyai daya antiseptik (Anonim, 2004). Menurut Gunawan dan Mulyani (2004), eugenol banyak diproduksi sebagai zat analgetik, stimulansia, korigen odoris, obat mulas, serta menghilangkan rasa mual dan muntah. Observasi Chaieb et al (2007) terhadap berbagai hasil penelitian menunjukkan bahwa eugenol terbukti memiliki aktivitas biologis sebagai antioksidan, antifungi, dan antiseptik.

Uapaya penegmbengan eugenol didasarkan pada besarnya produksi bahan baku bunga cengkeh di dalam negeri serta penggunaan senyawa eugenol yang luas dalam dunia pengobatan. Luasnya pemanfaatan eugenol belum didukung ketersediaan eugenol dalam jumlah yang cukup, sehingga diperlukan upaya-upaya untuk mengembangkan kuantitas dan kualitas eugenol, salah satunya dengan menentukan daerah sentra penghasil bahan baku bunga cengkeh dengan kandungan eugenol yang besar. Penelitian dilakukan dengan menentukan kundungan eugenol dalam minyak atsiri bunga cengkeh dari daerah di Maluku, Sumatera, Sulawesi, dan Jawa sebagai daerah sentra penghasil bahan baku bunga cengkeh di Indonesia.

\section{Bahan dan Alat yang digunakan \\ Bahan yang digunakan}

Sampel bunga cengkeh kering (Syzygium aromaticum L.) diperoleh dari daerah Amboyna (Maluku), Padang (Sumatera), Palopo (Sulawesi), dan Tawangmangu (Jawa).

Bahan kimia yang digunakan adalah eugenol (kemurnian 99\%; Sigma-Aldrich), etanol (Merck), metanol (p.a.; Merck), aquadest, $\mathrm{Na}$ sulfat anhidrat (Merck), toluene (Merck), gas Helium (He).

\section{Alat}

Alat yang diperlukan dalam penelitian ini adalah seperangkat alat gelas (Pyrex®), IWAKI ${ }_{\text {TE-32 }}$ Glass, Under Lic), seperangkat alat destilasi uap dan air, piknometer (Pyrex®), IWAKI $\mathrm{TE}_{\mathrm{TE}-32}$ Glass, Under Lic), refraktometer Abbe, seperangkat alat GC-MS (Shimadzu GC-2010 dilengkapi dengan detektor mass selektif Shimadzu GCMS-QP2010S).

\section{Jalannya Penelitian \\ Isolasi minyak atsiri bunga cengkeh}

Minyak atsiri bunga cengkeh diperoleh melalui metode destilasi uap dan air. Sebanyak $75 \mathrm{~g}$ bunga cengkeh kering dimasukkan dalam bejana destilasi uap yang sudah diisi aquadest sebanyak 5 liter. Sistem pendingin air dialirkan secara perlahan dan dijaga agar air tetap mengalir selama proses penyulingan berlangsung. Bejana dipanaskan sehingga minyak akan dibebaskan dari kelenjar minyak dalam jaringan tanaman. Destilat ditampung pada tempat penampung berskala. Penampungan minyak atsiri cengkeh dihentikan setelah tidak terjadi penambahan volume minyak atsiri selama 30-45 menit. Destilat yang diperoleh merupakan campuran minyak dengan air yang selanjutnya dipisahkan dalam corong pisah. Na sulfat anhidrat ditambahkan dalam minyak atsiri untuk mengikat adanya sisa air. Volume minyak yang diperoleh dicatat dan ditetapkan rendemen minyak atsiri yang diperoleh. Waktu destilasi yang dibutuhkan untuk menyari minyak atsiri dalam $75 \mathrm{~g}$ bunga cengkeh kering adalah 10-27 jam. Penetapan rendemen dilakukan 3 kali (triplo). Minyak atsiri yang diperoleh dari 3 kali proses destilasi dicampur dan disimpan dalam botol gelap agar terlindung dari cahaya dan disimpan ditempat yang sejuk. Rendemen minyak atsiri dinyatakan dalam \%(b/b) dalam bunga cengkeh.

Rendemen minyak atsiri (\%b/b) dalam bunga cengkeh $=$ Rendemen $(\% \mathrm{v} / \mathrm{b}) \times$ bobot jenis minyak terkoreksi $\left(25^{\circ} \mathrm{C}\right)$

\section{Pemeriksaan organoleptis minyak atsiri bunga cengkeh}

Pemeriksaan organoleptis dilakukan terhadap warna, rasa, dan bau minyak atsiri bunga cengkeh.

\section{Pemeriksaan bobot jenis minyak atsiri bunga cengkeh}

Bobot jenis minyak ditetapkan dengan menggunakan piknometer $(25,0 \mathrm{~mL})$. Piknometer dibersihkan dengan etanol dan dikeringkan. Piknometer kosong ditimbang dengan seksama. Piknometer diisi dengan aquadest hingga penuh dan dibuka tutup kapilernya. Piknometer direndam dalam air es 
hingga suhunya turun kira-kira $2^{\circ} \mathrm{C}$ di bawah suhu percobaan $\left(27^{\circ} \mathrm{C}\right)$ dan ditambahkan aquadest hingga piknometer kembali penuh. Piknometer diangkat dari air es, dibiarkan suhunya naik hingga suhu percobaan, kemudian ditutup pipa kapilernya cepat-cepat. Diusap air yang menempel, kemudian ditimbang dengan seksama. Bobot air dalam piknometer dihitung dengan cara:

Bobot piknometer + air $=a+b$ gram

Bobot piknometer kosong $=$ a gram -

Bobot air = $\quad$ gram

Volume piknometer ditentukan dengan cara:

Penetapan bobot minyak atsiri dalam piknometer sama seperti cara tersebut diatas. Jika diketahui bobot minyak atsiri bunga cengkeh tersebut $=\mathrm{c}$ gram, maka bobot jenis minyak atsiri bunga cengkeh ditentukan dengan:

Nilai bobot jenis minyak atsiri dikoreksi pada suhu $25^{\circ} \mathrm{C}$ agar dapat dibandingkan dengan Standar Nasional Indonesia (1996). Nilai koreksi bobot jenis minyak atsiri cengkeh untuk perubahan setiap $1{ }^{\circ} \mathrm{C}=0,00085$. Nilai koreksi harus ditambahkan jika pengukuran sampel diatas suhu $15^{\circ} \mathrm{C}$, dan dikurangi pada suhu dibawah $15^{\circ} \mathrm{C}$ (Ketaren, 1985). Nilai bobot jenis minyak atsiri pada suhu $25^{\circ} \mathrm{C}$ dihitung dengan cara:

Bobot Jenis $\left(25^{\circ} \mathrm{C}\right)=$ Bobot Jenis $\left(27^{\circ} \mathrm{C}\right)+$ (selisih suhu $\mathrm{x}$ nilai koreksi)

\section{Pemeriksaan indeks bias minyak atsiri}

Penetapan indeks bias minyak atsiri dilakukan dengan menggunakan alat refraktometer Abbe. Penutup prisma refraktometer dibuka dan pada bagian prismanya dibersihkan dengan kertas tissue yang dibasahi toluene. Refraktometer diletakkan di tempat yang terang kemudian aliran air dari kran dialirkan ke dalam lubang refraktometer (suhu percobaan $29^{\circ} \mathrm{C}$ ). Minyak atsiri diteteskan di atas permukaan prisma hingga merata kemudian ditutup kembali. Indeks bias dibaca pada lingkaran skala yang berupa garis perpotongan gelap dan terang. Nilai indeks bias minyak atsiri dikoreksi pada suhu $25^{\circ} \mathrm{C}$ agar dapat dibandingkan dengan Standar Nasional Indonesia (1996). Nilai koreksi indeks bias minyak atsiri cengkeh untuk perubahan setiap $1^{\circ} \mathrm{C}=0,00045$. Nilai koreksi tersebut harus ditambahkan jika pengukuran sampel diatas suhu $15{ }^{\circ} \mathrm{C}$, dan dikurangi pada suhu dibawah $15{ }^{\circ} \mathrm{C}$ (Ketaren,
1985). Nilai indeks bias minyak atsiri pada suhu $25^{\circ} \mathrm{C}$ dihitung dengan cara:

Indeks bias $\left(25^{\circ} \mathrm{C}\right)=$

Indeks bias $\left(29^{\circ} \mathrm{C}\right)+($ selisih suhu $x$ nilai koreksi)

\section{Analisis Gas Chromatography-Mass Spectrometry (GC-MS)}

Analisis dilakukan dengan menggunakan Shimadzu GC-2010 dilengkapi dengan detektor mass selektif Shimadzu GCMS-QP2010S dan kolom kapiler $\mathrm{Rxi}^{\mathrm{TM}}-1 \mathrm{~ms}(30 \mathrm{~m} \times 0,25 \mathrm{~mm}$, ketebalan film 0,25 $\mu \mathrm{m})$. Sistem ionisasi elektron untuk deteksi GC-MS menggunakan energi ionisasi sebesar $70 \mathrm{eV}$. Kecepatan alir helium sebagai gas pembawa diatur 1,0 $\mathrm{mL} /$ menit. Injektor dan $M S$ transfer line temperatures diatur pada 280 dan $245^{\circ} \mathrm{C}$, secara respektif. Suhu kolom dijaga pada $50^{\circ} \mathrm{C}$, ditingkatkan hingga $100^{\circ} \mathrm{C}$ dengan kenaikan $10^{\circ} \mathrm{C}$ /menit (ditahan selama 1 menit), kemudian ditingkatkan hingga $140{ }^{\circ} \mathrm{C}$ dengan kenaikan suhu $5{ }^{\circ} \mathrm{C} /$ menit, ditingkatkan kembali hingga $160{ }^{\circ} \mathrm{C}$ dengan kenaikan $2{ }^{\circ} \mathrm{C} /$ menit dan ditingkatkan hingga $245{ }^{\circ} \mathrm{C}$ dengan kenaikan 5 ${ }^{\circ} \mathrm{C} /$ menit. Waktu elusi tiap sampel adalah 20 menit

\section{Pembuatan kurva baku eugenol}

Standar eugenol berupa cairan, mempunyai bobot jenis $=1,066 \mathrm{~g} / \mathrm{mL}$ dan kemurniannya $99 \%$. Satu gram baku eugenol setara dengan $0,938 \mathrm{~mL}$. Stok eugenol $(1,0 \% \mathrm{~b} / \mathrm{v})$ dibuat dengan mengambil 50,0 $\mu \mathrm{L}$ standar eugenol dan dilarutkan dalam metanol p.a hingga $5,0 \mathrm{~mL}$. Konsentrasi Dibuat dala 5 seri, berturut-turut 0,$200 ; 0,100 ; 0,050 ; 0,025$ dan $0,013 \% \mathrm{~b} / \mathrm{v}$ dari larutan stok baku eugenol $(1,0 \% \mathrm{~b} / \mathrm{v})$.

Satu mikroliter $(1,0 \mu L)$ dari tiap konsentrasi disuntikkan ke dalam kolom. Kurva baku dibuat 3 kali (triplo) dengan replikasi pembacaan 2 kali. Persamaan kurva baku diperoleh melalui program regresi linier dengan memplotkan konsentrasi eugenol baku (\% b/v) versus luas area peak eugenol dan ditetapkan koefisian korelasinya.

\section{Penetapan batas deteksi dan batas kuantitasi}

Pengukuran batas deteksi dan batas kuantitasi dilakukan dengan mengolah data yang diperoleh dari hasil pengukuran linieritas standar sehingga diperoleh nilai Limit of Detection ( $L O D)$ dan Limit of Quantitation ( $L O Q$ ). $\angle O D$ dan $\angle O Q$ dihitung dengan menggunakan rumus: 
Keterangan:

$\mathrm{S}(\mathrm{y} / \mathrm{x})^{2}=$ variasi variable respon $(\mathrm{y})$

$Y=$ luas kromatogram rata-rata eugenol

$\mathrm{Yi}=$ luas area hitung dari persamaan regresi

$\mathrm{N}=$ jumlah seri konsentrasi

$\mathrm{b}=$ slope pada persamaan regresi

\section{Penetapan kadar eugenol dalam minyak} atsiri

Larutan stok sampel $(3,0 \% \mathrm{ob} / \mathrm{v})$ dibuat dengan menimbang $150,0 \mathrm{mg}$ minyak dan dimasukkan dalam labu takar 5,0 mL. Volume $5,0 \mathrm{~mL}$ dicapai dengan penambahan metanol p.a. Dibuat sampel $(0,1 \% \mathrm{ob} / \mathrm{v})$ dengan mengambil 33,0 $\mu \mathrm{L}$ larutan stok minyak $(3,0$ $\% \mathrm{~b} / \mathrm{v})$ dan dimasukkan ependorf $1,0 \mathrm{~mL}$. Volume $1,0 \mathrm{~mL}$ dicapai dengan penambahan metanol p.a. Satu mikroliter $(1 \mu \mathrm{L})$ sampel disuntikkan secara splitless. Sampel dianalisis 3 kali dengan replikasi pembacaan 2 kali. Komponen diidentifikasi dengan membandingkan waktu retensi relatif dan spektra mass yang ditunjukkan oleh larutan standar eugenol.

\section{Cara Analisis \\ Perhitungan kadar}

Luas area peak sampel dimasukkan ke dalam persamaan regresi linier standar:

$y=a+b x$

keterangan:

$y=$ luas area sampel;

$\mathrm{a}=$ intersep;

$\mathrm{b}=$ slope;

$\mathrm{X}=$ kadar eugenol dalam minyak atsiri yang akan dihitung $(\% \mathrm{~b} / \mathrm{v})$

Setelah diperoleh harga $\mathrm{x}$, dikalikan dengan faktor pengenceran ( $f p)$ dan dikembalikan ke berat sampel. Kadar eugenol dinyatakan dalam $\% \mathrm{~b} / \mathrm{b}$ dalam minyak atsiri bunga cengkeh.

keterangan:

$\mathrm{A}=\operatorname{kadar}(\mathrm{x})$ yang diperoleh dalam perhitungan $(\% \mathrm{~b} / \mathrm{v})$

Kadar eugenol (\%b/b) dalam bunga cengkeh kering diperoleh dengan cara memperhitungkan rendemen minyak atsiri $(\% \mathrm{~b} / \mathrm{b})$ tiap daerah.

Kadar eugenol $(\% \mathrm{~b} / \mathrm{b})$ dalam bunga cengkeh= Kadar eugenol $(\% \mathrm{~b} / \mathrm{b})$ dalam minyak $x$ rendemen dalam $100 \mathrm{~g}$ bunga cengkeh (gram)

\section{Analisis statistik}

Rendemen minyak atsiri bunga cengkeh dari keempat daerah dianalisis dengan metode analisis statistik Shaphiro-Wilk (uji normalitas) dan Kruskal- Wallis dengan uji lanjut Post Hoc
Mann- Whitney dengan nilai signifikansi 0,05. Kadar eugenol (\%b/b) dalam minyak atsiri dianalisis dengan metode analisis statistik Shaphiro-Wilk dan One way analysis of variance (ANOVA) dengan uji lanjut Post Hoc $\angle S D$ dengan nilai signifikansi 0,05 . Analisis statistik dilakukan dengan menggunakan SPSS Statistics 17.0 for Windows.

\section{HASIL DAN PEMBAHASAN}

Isolasi Minyak Atsiri Bunga Cengkeh

Minyak atsiri bunga cengkeh dari keempat daerah berwarna kuning muda jernih, berbau khas aromatik dan memiliki rasa pedas dan agak pahit. Rendemen minyak atsiri bunga cengkeh dari Maluku, Sumatera, Sulawesi, dan Jawa berturut-turut $15,21 \pm 0,40 ; \quad 15,05 \pm 0,41$; $14,14 \pm 0,00$ dan $14,09 \pm 0,00 \%$ b/b (Tabel 1). Hasil analisis statistik menunjukkan minyak atsiri yang berasal dari Maluku dan Sumatera mempunyai rendemen yang sama besar ( $p>0,05)$.

Kandungan minyak atsiri dalam bunga cengkeh kering adalah 10-20\%. Perbedaan tingkat rendemen minyak atsiri bunga cengkeh kering tersebut dapat dipengaruhi faktor yaitu daerah asal tanaman dan penanganan bahan sebelum penyulingan (Nurdjannah, 2004). Faktor-faktor tersebut dapat pula mempengaruhi kualitas minyak atsiri yang dihasilkan. Parameter penentu kualitas fisik minyak atsiri dapat diketahui melalui pemeriksaan bobot jenis dan indeks bias.

\section{Bobot Jenis Minyak Atsiri Bunga Cengkeh}

Bobot jenis merupakan salah satu kriteria penting dalam menentukan mutu dan kemurnian minyak atsiri. Bobot jenis minyak atsiri bunga cengkeh dari Maluku, Sumatera, Sulawesi, dan Jawa berturut-turut $(1,0533 \pm 0,00), \quad(1,0583 \pm 0,00), \quad(1,0605 \pm 0,00)$, $(1,0570 \pm 0,00) \quad$ (Tabel 1). SNI (1996) menyebutkan nilai mutu minyak atsiri bunga cengkeh mempunyai bobot jenis 1,030-1,060 pada suhu $25^{\circ} \mathrm{C}$. Minyak atsiri bunga cengkeh dari keempat daerah mempunyai bobot jenis sesuai dengan ketentuan yang ditetapkan Standar Nasional Indonesia (SNI): 06-42671996.

\section{Indeks Bias Minyak Atsiri Bunga Cengkeh} Indeks bias minyak atsiri bunga cengkeh dari Maluku, Sumatera, Sulawesi, dan Jawa berturut-turut $(1,5272 \pm 0,00), \quad(1,5314 \pm 0,00)$, $(1,5300 \pm 0,00)$, dan $(1,5308 \pm 0,00)$ (Tabel 1$)$. SNI (1996) menetapkan mutu minyak atsiri bunga cengkeh mempunyai indeks bias $\left(25^{\circ} \mathrm{C}\right)$ $1,527-1,535$. Minyak atsiri dari keempat daerah dapat dikatakan mempunyai sifat fisika yang baik terkait nilai indeks biasnya. 
Tabel 1- Hasil Rata-rata $(M e a n \pm S D)$ Rendemen, Bobot Jenis terkoreksi $\left(25^{\circ} \mathrm{C}\right)$, Indeks Bias terkoreksi $\left(25^{\circ} \mathrm{C}\right)$ Minyak Atsiri Bunga Cengkeh (Syzygium aromaticum (L.) Merr. \& Perry) yang berasal dari Daerah di Maluku, Sumatera, Sulawesi, dan Jawa

\begin{tabular}{ccccc}
\hline Daerah & Volume minyak $(\mathbf{m L})$ & $\begin{array}{c}\text { Rendemen } \\
(\% \mathbf{b} / \mathbf{b})\end{array}$ & $\begin{array}{c}\text { Bobot Jenis } \\
\text { terkoreksi }\left(\mathbf{2 5}{ }^{\circ} \mathbf{C}\right)\end{array}$ & $\begin{array}{c}\text { Indeks Bias } \\
\text { terkoreksi }\left(\mathbf{2 5}{ }^{\circ} \mathbf{C}\right)\end{array}$ \\
\hline Maluku & $11.00 \pm 0,00$ & $15,21 \pm 0,40^{*}$ & $1,0533 \pm 0,00$ & $1,5272 \pm 0,00$ \\
Sumatera & $11.00 \pm 0,29$ & $15,05 \pm 0,41^{*}$ & $1,0583 \pm 0,00$ & $1,5314 \pm 0,00$ \\
Sulawesi & $10.00 \pm 0,00$ & $14,14 \pm 0,00$ & $1,0605 \pm 0,00$ & $1,5300 \pm 0,00$ \\
Jawa & $10.00 \pm 0,00$ & $14,09 \pm 0,00$ & $1,0570 \pm 0,00$ & $1,5308 \pm 0,00$ \\
\hline Keterangan: ${ }^{*}$ = berbeda tidak signifikan & &
\end{tabular}

Kualitas minyak atsiri bunga cengkeh dievaluasi pula dari kandungan fenol, terutama eugenol (Guenther, 1990). Berbedanya rendemen, bobot jenis, dan indeks bias minyak atsiri dapat menyebabkan perbedaan kandungan kimia minyak atsiri bunga cengkeh (Ketaren, 1985) sehingga kadar eugenol sebagai senyawa mayor perlu ditetapkan secara kuantitatif.

\section{Penetapan Kadar Eugenol Minyak Atsiri Bunga Cengkeh}

Penetapan kadar senyawa eugenol dilakukan dengan metode analisis GC-MS Metode ini utamanya digunakan untuk penetapan kualitatif dan kuantitatif senyawa yang mudah menguap (Clark, 2007). Bagian GC digunakan sebagai pemisah komponen eugenol dari komponen lain dan MS digunakan sebagai pendeteksi keberadaan eugenol disamping penggunaan standar eugenol sebagai penanda. Persamanan kurva baku menyatakan hubungan yang linier antara konsentrasi dengan luas area peak. Persamaan kurva baku yang diperoleh adalah $y=7.052 .025,443 x-29.596,774$ dengan nilai koefisien korelasi $|r|=0,99897$.

Penentuan sensitivitas metode dilakukan dengan mengolah data yang diperoleh dari hasil pengukuran linieritas standar sehingga diperoleh nilai $\angle O D$ dan $\angle O Q$. $\angle O D$ didefinisikan sebagai konsentrasi terkecil yang dapat dideteksi namun tidak perlu secara kuantitatif, sedangkan pada definisi $L O Q$ dinyatakan sebagai konsentrasi terkecil analit yang dapat diukur secara kuantitatif (Novelina dkk., 2009). Secara statistik, perhitungan batas deteksi dan batas kuantitasi diperoleh melalui garis regresi linier dari kurva kalibrasi standar eugenol. Hasil perhitungan diperoleh nilai $L O D$ sebesar $0,01198 \%$ b/v dan nilai $L O Q$ sebesar 0,03994 $\% \mathrm{~b} / \mathrm{v}$.

Penentuan selektivitas metode GC-MS dengan membandingkan kromatogram standar dengan blanko. Hasil uji selektivitas menunjukkan peak area pada retention time (RT) 13,994 menit merupakan senyawa eugenol (Gambar 1). Identifikasi senyawa eugenol dalam sampel dilakukan dengan membandingkan waktu retensi relatif dan spektra mass standar eugenol pada WILLEYS library. Spektogram massa senyawa eugenol menunjukkan analisis fragmentasi (m/z): 164 $\mathrm{M}^{+}$dan $149\left(\mathrm{M}-\mathrm{CH}_{3}\right)^{+}$(Gambar 2). Data spektra massa eugenol menunjukkan ion molekuler yang paling stabil pada 164 sesuai dengan massa molekul relatif eugenol. Fragmen pada 149 sesuai dengan hilangnya gugus metil pada rantai samping.

Kromatogram GC menunjukkan eugenol sebagai komponen utama minyak atsiri bunga cengkeh dari daerah di Maluku (Gambar 3), Sumatera (Gambar 4), Sulawesi (Gambar 5), dan Jawa (Gambar 6). Waktu retensi eugenol dalam sampel sesuai dengan standar yaitu 13,980-13,991 menit. Kuantitas komponen eugenol dalam minyak atsiri bunga cengkeh dari Maluku, Sumatera, Sulawesi dan Jawa berturut-turut $(93,17 \pm 1,72 \% \mathrm{~b} / \mathrm{b})$, $(60,29 \pm 0,67 \% \mathrm{~b} / \mathrm{b}), \quad(65,66 \pm 0,80 \% \mathrm{~b} / \mathrm{b}), \quad$ dan $(55,88 \pm 0,98 \% b / b)$ (Tabel 4$)$. Kadar eugenol $(\% \mathrm{~b} / \mathrm{b})$ minyak atsiri bunga cengkeh dari keempat daerah berbeda signifikan $(p<0,05)$ pada uji One way ANOVA dan Post Hoc LSD. Kadar eugenol tertinggi dalam minyak atsiri diperoleh dari Maluku diikuti daerah di Sulawesi, Sumatera, dan Jawa.

Kandungan eugenol dari berbagai daerah menunjukkan hasil yang berbeda, minyak atsiri bunga cengkeh yang berasal dari Turki mengandung 87,00\% (Alma et al, 2007), Barcelona (Spanyol) 85,50\% (Viuda et al, 2007) dan Kairo (Mesir) yaitu 71,56 \% (Nassar et al, 2007). SNI (1996) menyatakan mutu minyak atsiri bunga cengkeh ditentukan kandungan eugenolnya yaitu sebesar $80-95 \%$. Minyak atsiri bunga cengkeh dari daerah di Maluku memiliki kualitas yang paling baik terkait kandungan eugenolnya. Berdasarkan hasil berbagai penelitian terdapat variasi dalam kandungan kimia dari minyak atsiri bunga cengkeh yang diperoleh dari berbagai daerah maupun berbagai negara. Variabilitas ini bergantung pada beberapa faktor meliputi iklim, musim, lokasi geografis, dan geologi (Viuda et al, 2007) 


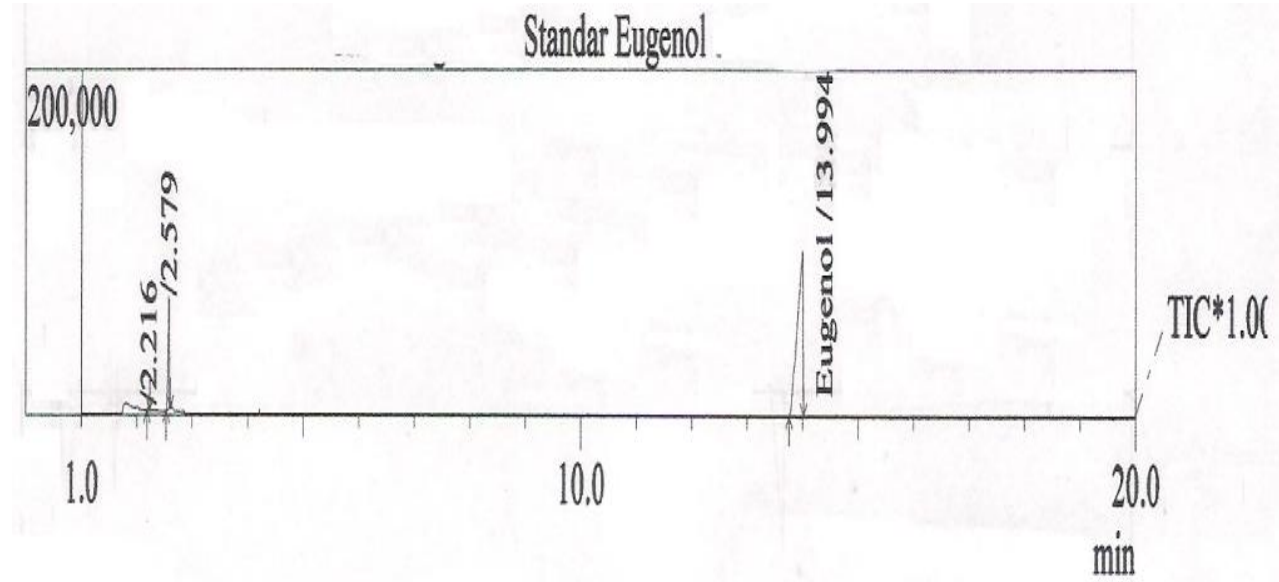

Gambar 1- Kromatogram Standar Eugenol (Rt=13,994 menit)

$$
\text { Spectrum Comparison }
$$

Spectruml wDstall std2.20.1=691914.qgd R.Time:13.992(Seant:1560) MassPeaks 26

RswMode:Averaged 13.983-14.000(1559-1561) BasePeak: $164.05(1000)$

BG Mode:Calc, from Peak Group 1- Eveat 1

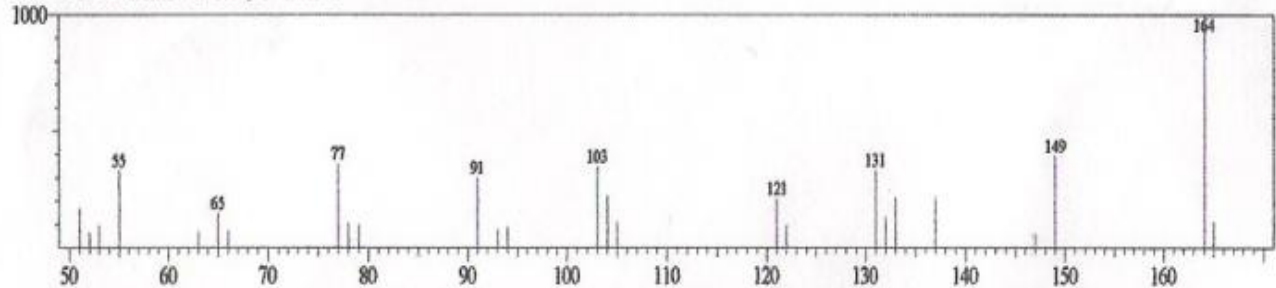

Gambar 2.- Fragmentasi peak eugenol (Rt=13,994 menit)Spektrogram Massa Standar Eugenol

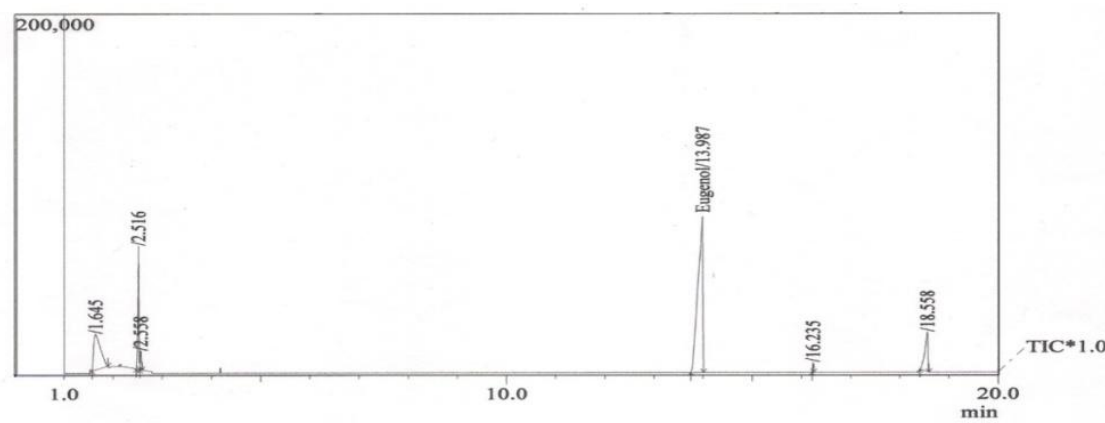

Gambar 3- Kromatogram Gas Eugenol pada Sampel Minyak Atsiri Bunga Cengkeh dari Daerah di Maluku. Kandungan eugenol dalam minyak atsiri sebesar $(93,17 \pm 1.72 \% \mathrm{~b} / \mathrm{b})$.

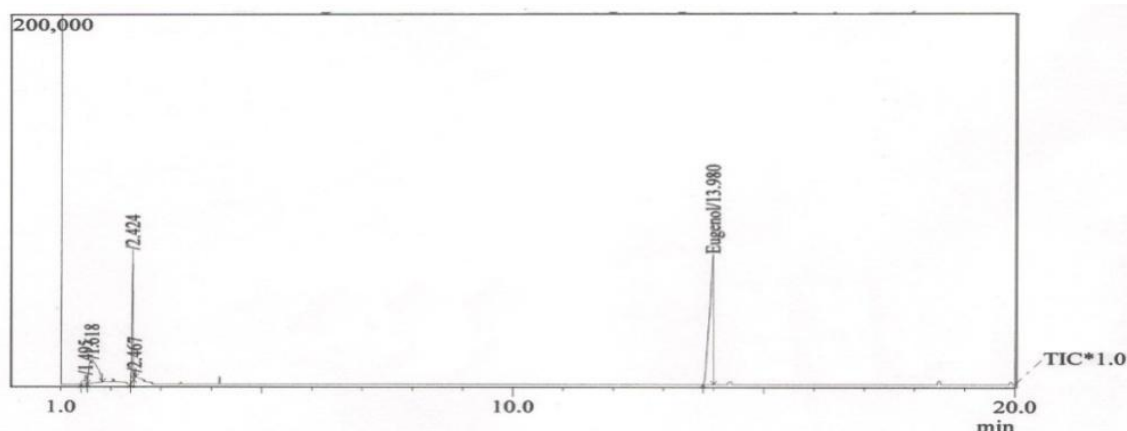

Gambar 4-Kromatogram Gas Eugenol pada Sampel Minyak Atsiri Bunga Cengkeh dari Daerah di Sumatera. Kandungan eugenol dalam minyak atsiri sebesar $(60,29 \pm 0,67 \% \mathrm{~b} / \mathrm{b})$. 


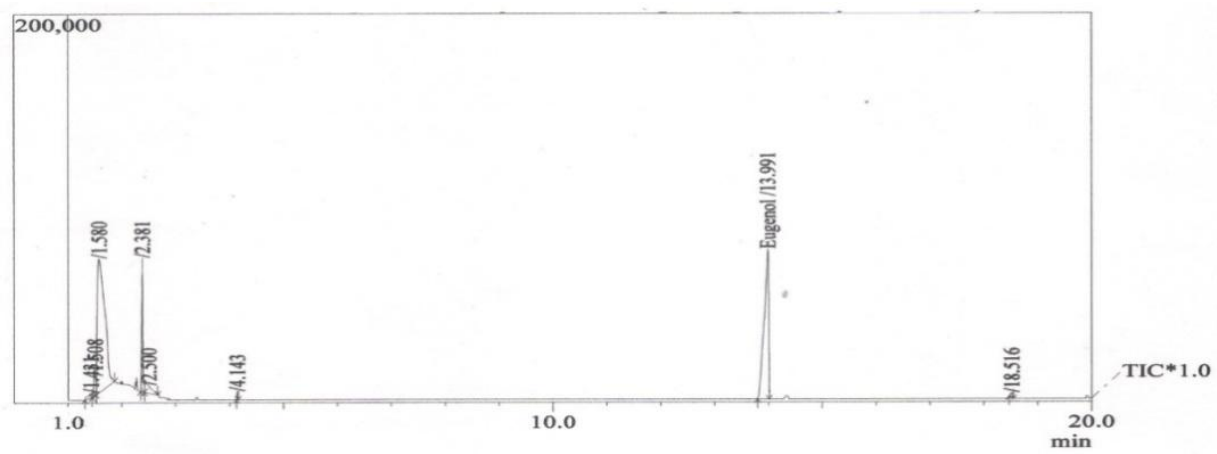

Gambar 5- Kromatogram Gas Eugenol pada Sampel Minyak Atsiri Bunga Cengkeh dari Daerah di Sulawesi. Kandungan eugenol dalam minyak atsiri sebesar $(65,66 \pm 0,80 \% \mathrm{~b} / \mathrm{b})$.

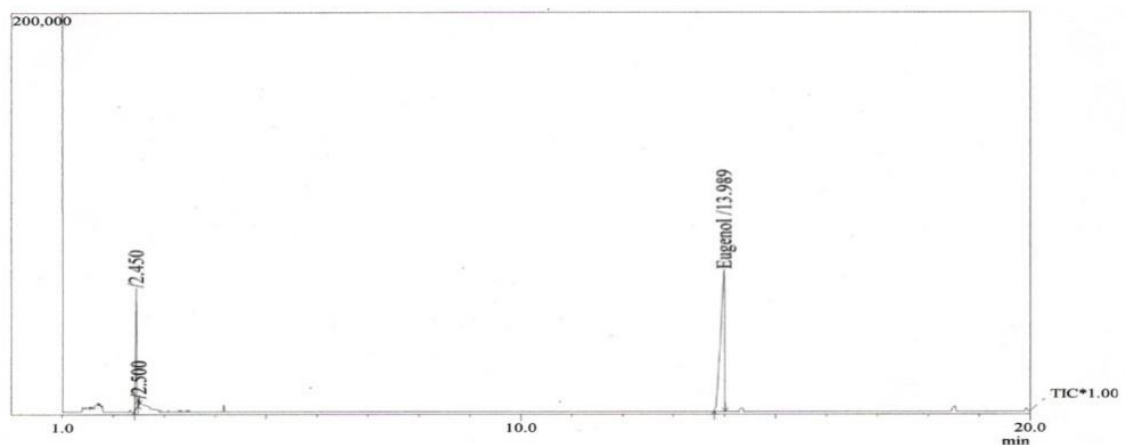

Gambar 6- Kromatogram Gas Eugenol pada Sampel Minyak Atsiri Bunga Cengkeh dari Daerah di Jawa. Kandungan eugenol dalam minyak atsiri sebesar $(55,88 \pm 0,98 \% \mathrm{~b} / \mathrm{b})$.

Tabel 2- Data Hasil Penetapan Kadar Eugenol (\%b/b) dalam Sampel Minyak Atsiri dan dalam Bunga Cengkeh

\begin{tabular}{|c|c|c|c|}
\hline \multirow{2}{*}{ Daerah } & \multirow{2}{*}{ Luas area } & \multicolumn{2}{|c|}{ Kadar eugenol $(\% \mathrm{~b} / \mathrm{b})$} \\
\hline & & dalam minyak atsiri & dalam bunga cengkeh kering \\
\hline \multirow{3}{*}{ Maluku* } & 616926 & 92,53 & 14,29 \\
\hline & 634535 & 95,12 & 14,03 \\
\hline & 612142.5 & 91.85 & 14,18 \\
\hline \multicolumn{2}{|r|}{ Mean $\pm S D$} & $93,17 \pm 1,72$ & $14,17 \pm 0,13$ \\
\hline \multirow{3}{*}{ Sumatera ${ }^{*}$} & 390792 & 60,17 & 9,08 \\
\hline & 387416 & 59,69 & 8,85 \\
\hline & 396337 & 61,00 & 9,04 \\
\hline \multicolumn{2}{|r|}{ Mean $\pm S D$} & $60,29 \pm 0,67$ & $9,08 \pm 0,25$ \\
\hline \multirow{3}{*}{ Sulawesi $i^{*}$} & 428238 & 65,53 & 9,27 \\
\hline & 424092.5 & 64,93 & 9,18 \\
\hline & 435138 & 66,52 & 9,41 \\
\hline \multicolumn{2}{|r|}{$M e a n \pm S D$} & $65,66 \pm 0,80$ & $9,28 \pm 0,0,11$ \\
\hline \multirow{4}{*}{ Jawa* } & 352390,7 & 56,35 & 7,94 \\
\hline & 359804.8 & 54.75 & 7.71 \\
\hline & 355866 & 56,54 & 7,97 \\
\hline & Mean $\pm S D$ & $55,88 \pm 0,98$ & $7,87 \pm 0,14$ \\
\hline
\end{tabular}

Keterangan: ${ }^{*}=$ berbeda signifikan

\section{KESIMPULAN}

Kandungan eugenol dalam minyak atsiri bunga cengkeh dari Maluku, Sumatera, Sulawesi, Jawa secara berturut-turut $(93,17 \pm 1,72 \% b / b), \quad(60,29 \pm 0,67 \% b / b)$,
$(65,66 \pm 0,80 \% b / b), \quad$ dan $\quad(55,88 \pm 0,98 \% b / b)$. Maluku merupakan penghasil minyak atsiri bunga cengkeh dengan kandungan eugenol paling tinggi diikuti daerah Sulawesi, Sumatera, dan Jawa.

\section{DAFTAR PUSTAKA}

Alma, M.H., Ertas, M., Nitz, S., Kollmannsberger, H., 2007, Essential Oil Content, Turkish Cloves, BioResources 2(2), 265-269

Anonim, 2004, Prospek dan Arah Pengembangan Agribisnis Cengkeh, 11-13, Direktorat Jenderal BP Perkebunan, Jakarta

Anonim, 2008, Menghasilkan Minyak Daun Cengkeh Bermutu, Warta Penelitian dan Pengembangan Pertanian, Vol. 30, No.5, 5-7 
Busroni, 2000, Sintesis 1-(3,4 Dimetoksi Fenil)-2-Propanon Turunan Eugenol Melalui Pembentukan Senyawa 1-(3,4 Dimetoksi Fenil)-2-Propanil Format pada Suhu 250-300 ${ }^{\circ} \mathrm{C}$, Jurnal ILMU DASAR, Vol. 1, No.I, 35-45

Chaieb, K., Hajlaoui, H, Zmantar, T., Nakbi, A.B., Rouabhia, M., Mahdouani, K., Bakhrout, A., 2007, The Chemical Composition and Biological Acivity of Clove Essential Oil, Eugenia caryophyllata (Syzygium aromaticum L. Myrtaceae): A Shot Review, Phytotherapy Research, 21: 501-506

Clark, J., 2007, Kromatografi Gas-Cair, (online), (http://www.chem-is-try.org, diakses tanggal 5 Oktober 2009)

Guenther, E., 1990, Minyak Atsiri, diterjemahkan oleh Ketaren, S., Jilid IVB, 481-492, Universitas Indonesia (UI-Press), Jakarta

Gunawan, D., dan Mulyani, S., 2004, IImu Obat Alam (Farmakognosi), Jilid I, 119, Penebar Swadaya, Jakarta

Gunawan, W., 2009, Kualitas dan Nilai Minyak Atsiri, Implikasi pada Pengembangan Turunannya, Seminar Nasional Kimia Bervisi SETS (Science, Environment, Technology, Society) Kontribusi Bagi Kemajuan Pendidikan dan Industri, Semarang, 1-11

Ketaren, S., 1985, Pengantar Teknologi: Minyak Atsiri, 57, 61-69, 133-144, Balai Pustaka, Jakarta

Nassar, M.I., Gaara, A.H., El-Ghorab, A.H., Farrag, A.R.H., Shen, H., Huq, E., Mabry, T.J., 2007, Chemical Constituents of Clove (Syzygium aromaticum, Fam. Myrtaceae) and Their Antioxidant Activity, Rev. Latinoamer. Quim, 35: 47-56

Novelina, Y.M., Sutanto, Fatimah, A., 2009, Validasi Metode Analisis Penetapan Kadar Senyawa Siklamat dalam Minuman Ringan, Prosiding PPI Standarisasi, Jakarta

Nurdjannah, N., 2004, Diversifikasi Bunga Cengkeh, Indonesian Center for Agricultural Postharvest Research and Development, Vol. 3, No.2, 61-70

Viuda, M.M., Ruíz, N.J., Fernández, L.J., Pérez, Á.A., 2007, Chemical Composition of the Essential Oils Obtained From Some Spices Widely Used in Mediterranean Region, Acta Chim. Slov, 921926 